\title{
JINNAH AND THE THEATRE OF POLITICS
}

\author{
Faisal Devji \\ University of Oxford
}

\begin{abstract}
In this essay I will look at the way in which Pakistan's founder, Mohammad Ali Jinnah, managed to lead Muslims without claiming to resemble them in any way. His heretical background, anglicized character and sheer arrogance instead served to augment rather than detract from Jinnah's popularity, because he represented a politics based on novelty rather than heredity, artifice rather than authenticity. Muslim politics in colonial India was founded upon the rejection of blood-and-soil forms of nationality, which could only define the Prophet's followers there as a minority and not a nation. Pakistan therefore had to be fought for in the purely ideal terms of a political logic, whose iconic representation was to be found in the biography of the man hailed as its creator.
\end{abstract}

Keywords: Hinduism, India, Islam, Mohammad Ali Jinnah, Nationalism, Pakistan.

\section{Resumen}

En este artículo estudio cómo el fundador de Paquistán, Mohammad Ali Jinnah, consiguió ser el líder de los musulmanes a pesar de su comportamiento herético, educación británica y arrogancia que, lejos de alejarlo de las masas, apuntalaron su popularidad. Jinnah venía a representar una política basada en la iniciativa más que en la búsqueda de lo tradicionalmente auténtico. La política musulmana en India rechazaba el nacionalismo por pertenencia a un espacio físico, que habría reducido a los seguidores del Profeta a una minoría, no a una nación. Por eso la idea de Paquistán se forjó en términos de lógica política y la representación más icónica de aquella era la biografía de su creador.

Palabras clave: hinduismo, India, islam, Mohammad Ali Jinnah, nacionalismo, Paquistán. 


\section{INTRODUCTION}

It is possible to imagine India achieving independence without a Gandhi or Nehru at the helm, and in fact historians routinely quarrel about what freedom might have looked like for her without these founding fathers. But nobody has ever been able to think of Pakistan's birth without Mohammad Ali Jinnah. Indeed historians regularly argue that if Jinnah had died a year before he actually did, Pakistan may never have come into being. Though far less influential internationally than his illustrious rivals, Jinnah is the one indispensable figure in the history of India as much as Pakistan. Jinnah's career serves to exemplify an extraordinarily dynamic period in the political life of India, when the limits not only of European imperialism, but of liberal nationalism, as well, were being tested in creative ways much beyond the tradition of British political thought. For in many ways his radically novel idea of Pakistan, with its lack of any prior history, conceptual as much as geographical, and with its two wings audaciously separated by a thousand miles of Indian territory, belonged to the twentieth-century world of ideological politics on a global scale. Indeed Pakistan can be said to have appeared on the world's map so as to confound any naturalized vision of the nation-state, dispensing as it did with every notion of territorial or cultural integrity for a political artifice.

Pakistan does not belong in the nineteenth-century context of nationalism, with its emphasis on common histories, geographies and traditions that were based on language or ethnicity. And I shall argue here that the abstract and even empty identity that constituted the single foundation for this country can be found mirrored in the biography of its founding father. For by his words as much as his character, Jinnah represented a denial of blood-and-soil forms of nationalism that relied upon notions of heredity, authenticity and intimacy. Whether by accident or design, Jinnah was the perfect father for a Pakistan created as a piece of theatre, the representation of an idea that had little if anything to do with the kind of nationalism characterized by deep histories and geographical continuities - all of which could only bind Muslims to an India in which they were forever doomed to be a minority.

\section{THE OBSCURITY OF ORIGINS}

Ever since he entered public life in the early years of the last century, Jinnah's character had been defined by an apparent contradiction. He was remarkably reticent about his background and private life on the one hand, while being flamboyant in his dress and comportment on the other (see Wolpert 1984). This contradiction could be seen in every part of Jinnah's personality, with his well-known shyness and sensitivity being compensated for by a sometimes rude and always self-assured manner. This character trait allowed Jinnah to make of Indian politics a piece of theatre whose action concealed as much as it revealed. His friends as well as enemies strove throughout Jinnah's career to understand not only what he was really up to but also who he really was. Jinnah himself was determined to remain an enigma. 
He wrote very little, apart from speeches, a few articles and brief, workaday letters, extraordinary in a period when Indian leaders like Gandhi and Nehru wrote tomes.

While it was no doubt born out of his own experience and psychology, this contradiction of personality might also have had something to do with Jinnah's ethnic and religious background. For the man who would be acclaimed as the Qaide-Azam or Great Leader of his people was in fact the most unlikely of Muslim politicians, coming as he did from a small community of Gujarati traders who declared one of the most heretical versions of Islam as their ancestral faith. A branch of the minority Shia sect, the Ismaili creed professed by these Khoja merchants dispensed with the religious law altogether and was open to considering Muhammad and his successors as incarnations of ostensibly Hindu deities like Vishnu. Indeed the Khojas rarely used the name Muslim for themselves, though they acknowledged Islam as their religion.

Out of step with the majority of India's Muslims, and even execrated by many among them, the Khojas emerged as a prosperous and influential trading community in cities like Bombay and Karachi during the nineteenth century, finding their business partners and clients among Hindus, Jains, Parsis and other Shia or Gujarati Muslim merchant groups. All this was true of Jinnah's father, a Karachi businessman hailing from the small Hindu princely state of Gondal. Given their relative distance from what passed as Muslim norms in India, and their greater intimacy with Hindu mores in particular, it had always struck men like Gandhi and Nehru as astounding that the Khojas could have produced a leader like Jinnah, whom they very frequently described as being more Hindu than Muslim. And in this they were quite correct, since Nehru, scion of a family that had served the Mughals, represented the dominant Muslim culture of North India in his dress and language, while Gandhi was certainly more knowledgeable about the Quran and Muslim devotions than the famously irreligious Jinnah.

Jinnah's Khoja background necessarily made his claims regarding both Hindus and Muslims into histrionic ones, since his intimacy was and in fact continued in his closest friendships to be with Hindus, Parsis, Christians and other Shias rather than with the vast population of Sunnis that he claimed to represent. Jinnah's intimate self, in other words, stood at some distance from his public persona. As a Khoja, Jinnah's relations with the majority of India's Muslims were distant apart from any personal inclination, while his links with Hindus in particular were close and even intimate. His partisanship of the country's Muslims had little to do with any personal experience or identification with them. Indeed it was precisely his distant and as it were "secular" definition of Islam that allowed Jinnah to transform Muslim identity into a modern and non-theological political form. And given the ambiguous position that he occupied between Hindus and Muslims, it is not surprising that Jinnah came to be convinced that it was the intimacy between these groups that made them vulnerable to hurt and posed the greatest political problem for India.

One of Jinnah's great enemies, the Hindu nationalist leader Savarkar, made the same kind of argument in his polemical tract of 1926 called Hindutva, where he argued that while Hinduism was by its nature pluralistic and tolerant, it was the otherwise admirable intimacy that groups such as the Khojas enjoyed with its 
followers that forced the latter to draw a line excluding outsiders from their inner being, though of course the Khojas were free to rejoin the parent body of Hinduism and be welcomed into it (Savarkar 101-102). Jinnah eventually reached the same conclusion, to sunder the ties of a cruel brotherhood that bound India's two great religions together with the hurt of fraternal betrayal, so that a genuine friendship could emerge in its place. This intimacy was on full view in Jinnah's relations with Gandhi, which were marked precisely by their regional, linguistic and trading-caste commonalities. The President of the Muslim League would assert that he knew how to deal with the Mahatma of the Indian National Congress, since he spoke to him as a Khoja did to a Bania, which is to say as a member of one Gujarati trading community to another (Khan 1976: 44).

\section{ACTING THE PART}

For someone who was admired as well as accused in later years of being so highly westernized in his language, attitudes and behaviour, Jinnah came from a completely Indian family background in which English was neither spoken nor indeed understood. Eventually his father picked up enough English to do business with British companies, and the young Mohammad Ali and his siblings are described by his sister, Fatima, as imitating the sound of English conversation: ish-phish-ishphish-yes being answered with ish-phish-ish-phish-no (Jinnah and al Mujahid 48). Even at the end of his life, by which time English had long become his preferred language, Jinnah neither spoke nor wrote it with any degree of sustained accuracy. And while his knowledge of Urdu, the official language of Muslim nationalism, was poor, Jinnah apparently spoke Gujarati and Kutchi beautifully if never in public, and seems even to have had a working knowledge of Persian, which he sometimes interjected into Urdu speeches when he couldn't remember the grammatical gender of certain words.

This disparity between his formidably anglicized demeanour, so utterly convincing to most observers, and a fundamental inability to assume complete mastery over the culture of the Raj, was also evident in other aspects of Jinnah's life. So his Calcutta lieutenant, M.A.H. Ispahani tells us that when he once offered to get Jinnah some bowties on a trip to Paris, his leader surprised him in admitting that he used ready-made ones, after which Ispahani taught Jinnah to tie these signs of European high culture by practising doing so around his thigh (Ispahani 99). It was almost as if Jinnah, far from rejecting his background to become a "brown Englishman," was content to treat his westernized self as a kind of role there to convince others but not pushed beyond the bounds of theatre to become a form of conversion or self-delusion. And theatre in this sense was of the essence in Jinnah's personality, allowing him to advance a persona while retreating from it at the same time, and to make audacious decisions or outrageous claims as part of the spectacle of politics.

This character trait became evident early in Jinnah's life. When this son of a petty trader who'd done well was sent off to London as an apprentice to a firm of port wine merchants with whom his father did business, he suddenly decided 
to abandon a promising commercial career and, much against his father's wishes, become a lawyer. The only other future he'd envisaged for himself was that of an actor, with Jinnah confessing that his great ambition had been to play Romeo on stage (Jinnah and al Mujahid 80). Given his early political career as the "ambassador of Hindu-Muslim unity", this choice of character is illuminating, since apart from being a lover, Romeo is a tragic hero who sought to reconcile two warring families but succeeds only in undoing himself in the process. Savarkar, writing at around the same time as Jinnah had left a Congress that had been revolutionized under Gandhi's leadership, would also refer to Romeo and Juliet to describe the intimacy of religious conflict in India (Savarkar 1-2).

Jinnah's love for theatre, both Bombay's Gujarati-language stage and the English one of Shakespeare, Wilde and Shaw, was evident from his library and conversation. Facing a choice between the stage and the law, he opted for the latter, and in doing so only chose a version of the stage. The young Jinnah was fascinated by the sheer theatre of politics, and saw the law as his ticket of entry into this world dominated by his social superiors. For as the patrician Nehru, a graduate of Harrow and Cambridge, would sneeringly remark in times to come, Jinnah was man of no cultivation or systematic reading, having never been to a university. In this he was much like Gandhi, both being autodidacts from traditional mercantile backgrounds, though the Mahatma's recourse to the language of native authenticity made him acceptable to Nehru by the same token that Jinnah's claim to the West rankled i him.

\section{A DANDY'S CODE OF HONOUR}

The young wife to whom his marriage had been arranged just before he'd left for London was dead, and his father on the verge of bankruptcy. Taking charge of the family, he managed to set up a precarious legal practice in Bombay and moved them all there, ensconcing his father and younger siblings in Khoja Mohallah, the traditional community neighbourhood in the "native quarter," while he took modest rooms in the colonial city near Apollo Bunder, where the Gateway of India stands today. India's great commercial metropolis, Bombay exerted a magnetic attraction for all those who wished to make their name and fortune, with Jinnah just one of many young men drawn there from provincial towns like Karachi. He behaved in exactly the way that the son of an Indian trader was expected to, working hard to support his suddenly impoverished family, educating his brothers and sisters and eventually marrying most of them off.

But the young man whose family lived in Khoja Mohallah was a very different individual from the aspiring lawyer who lived in the colonial city and was soon to become a rising star of the Indian National Congress. And in this sense the fact that Jinnah's life was divided between two very different parts of Bombay was indicative of his ambiguous personality more generally. For while Jinnah did not seem to be particularly close to his family, apart from his father and sister Fatima, he was impeccable in doing his duty by them. Similarly, he appears to have had little fondness for the city's various "native" mohallahs or quarters, though he depended 
upon them for much of his career. For Jinnah was a representative of Bombay's Muslims in the separate religious electorates that were created by the colonial state just before the First World War, and gradually expanded by the colonial state until its dissolution.

But if Jinnah didn't bring the world of the mohallah to his practice at the Bombay High Court, neither did he simply accommodate himself to that institution's conventions and expectations, displaying instead a propensity to outrage the very respectability he seems otherwise to have craved. More than a propensity, this desire to claim the norms of a certain culture only to break them may be described as an urge fundamental to Jinnah's personality, one that was evident in this initial phase of his legal career in the young Mohammad Ali's unprecedentedly rude and risky remarks in court to judges both British and Indian. It was the kind of arrogance that was taken as a sign of nationalism once Jinnah's political career had begun, but that he exercised far more routinely and generally with no political intent. By such behaviour Jinnah may have sought to outrage the very society into which he wanted admittance, but not because he had already mastered its ways and become an insider. On the contrary, he appears to have entertained a degree of contempt for the insider's conventionality, and sought to guard against it by stressing the sheer individuality of his will.

This high-risk strategy of pushing the margins of respectability, and therefore situating himself at their edges, also took the form of dandyism, with Jinnah fashioning himself into an exquisitely dressed gentleman of a distinct kind, laconic and epigrammatic. This studied and possibly ironic pose, complete with monocle and cigarette holder, was much commented upon during his lifetime, when journalists, for example, often prefaced their weightiest interviews of Jinnah with descriptions of his elegance, as if they were writing for society magazines. Whether in European or Indian dress, Jinnah flouted sartorial convention. On the one hand his two-tone shoes and double-breasted suits with their exaggerated lapels belonged more to the fashionable man about town than to the lawyer and politician that he actually was. On the other hand Jinnah's north Indian sherwani was topped by a karakuli cap, which not only bore a striking resemblance to the cap still worn at prayer by the Khojas of Bombay, but which was also donned at a rakish angle as if in defiance of religious opinion, for which this indicated a dissolute character.

Dandyism, its first great theorist Charles Baudelaire tells us, emerges during times of transition, when the position of entire social classes is shifting, and certain men find themselves caught between them (Baudelaire 28). Thrown upon his own devices rather than the conventions of inheritance, the dandy's art is as much about the discipline of self-making as it is about ephemeral pleasures. Jinnah's dandyism was also a form of stern discipline, as ascetic in its own way as any of Gandhi's habits. And the discipline he showed in his dress and deportment, making no concessions to comfort and the Indian climate, was mirrored in every aspect of his political life. This included a rigorous schedule as well as otherwise pointless and even obsessive activities like painstakingly filling out receipts for the most minor sums donated to the League or turning off unnecessary lights. 
Together with his appearance and behaviour came a distinctive speaking style, one that carried effect even when Jinnah wasn't being rude. As we may expect, what he was most concerned about in his public utterances was the theatre of appearances, and Jinnah's courtroom manner is still recalled as part of the Bombay High Court's lore. Because his voice wasn't very strong, Jinnah varied its timbre and emphasized the cadences of his delivery, which he accompanied by arresting gestures. What he eventually produced thereby was a unique mode of political speech in a time that came to be dominated by leaders declaiming from balconies to assembled masses. Of course none of the leaders who dominated Indian opinion during the age of mass politics in the 1930s and 1940s, Gandhi, Nehru and Jinnah, ever made use of declamation or its militaristic potential, with Gandhi speaking in a rather monotonous and matter-of-fact way, while Nehru imitated a certain highflown and high-pitched English style with the kind of fidelity that Jinnah despised.

Jinnah's prose, marked as it was with grammatical infelicities, was neither as spare as Gandhi's nor as rhetorically accomplished as Nehru's. But what it lacked by way of content was more than made up for by a dramatic delivery and fine use of silence. Indeed Jinnah is the only one of the three about whose speaking style we have a great deal of description and commentary, all of which concurs in stating that its power resided not in projecting the force of Jinnah's personality outwards with his voice, but rather in drawing an audience inwards by the deployment of low and sometimes almost inaudible tones (Moraes 181). In fact Jinnah's oratorical secret seems to have been his ability to turn even speeches to mammoth audiences into the kind of private, exclusive and even intimate performances that might be associated with courtrooms and drawing rooms. His low but perfectly modulated voice and elegance of gesture apparently transformed large and rambunctious Indian crowds into quiet and attentive audiences, to the extent that during Jinnah's speeches we hear almost none of the exhortations to silence and discipline that were so common at Gandhi or Nehru's public appearances.

Reducing one's interlocutors to silence, which is something Jinnah did quite regularly not only to his audiences but also his associates in the working committee of the Muslim League, is not necessarily a democratic skill, though it certainly demonstrates the hypnotic quality of Jinnah's charisma. And indeed when he met Gandhi for their last session of intense negotiations in 1944, the Mahatma greeted Jinnah by saying that he had "mesmerised the Muslims," to which the Great Leader of his people responded by remarking that Gandhi had "hypnotized the Hindus," each man seeming to realize that however hedged it might be by the procedures of democratic institutions like political parties, his power in drawing the adulation of millions derived from a quite different source (al Mujahid 90). Of course all this was to come in the future, but it is clear that Jinnah's political style had its origins in his early career, when the only audiences he sought to dominate were to be found in courtrooms and drawing rooms. 


\section{REPRESENTING THE FUTURE}

A rising star in India's political firmament, hailed by the poetess and Congress propagandist Sarojini Naidu, one of his many female admirers, as the "ambassador of Hindu-Muslim unity," Jinnah truly represented the future of India herself in a period whose end coincided with that of the First World War. He envisioned his task as bringing Muslims into the mainstream of Indian politics. Then divided into many associations, some of the "modern" among these followers of the Prophet were gathered in the Muslim League. The party had been founded in 1906, by a collection of Bombay-based merchants, rich aristocrats and anglicized North Indian Sunnis, to defend Muslim interests once the British had announced the introduction of limited political representation. Jinnah thought that India's vast Muslim population possessed no politics of its own, and he was determined to have it play its proper role in the struggle for India's freedom. His great triumph in this endeavour came with the Lucknow Pact in 1916, which brought Congress and League together on a single platform and allowed for a common membership between them.

Even after he had abandoned the Congress in 1920, Jinnah did not cease to work for a political agreement between Hindus and Muslims, though what he meant by this was a genuine coming together and not merely the latter's dissolution in a Hindu-dominated Congress, which he thought was only a recipe for future confrontation. His last such effort was made during the 1937 elections, when, despite his estrangement of more than a decade from the Congress, Jinnah returned from his English exile and took over the Muslim League, with a view to bringing it closer to the former. Even when he had become Congress's greatest enemy, Jinnah continued to hold up Hindu politicians, and the party that he thought they dominated, as models for Muslims. Indeed with the exception of the Prophet's followers in Bombay, among whose trading communities he counted himself, Jinnah was openly and routinely contemptuous of the generality of Indian Muslims, as far as their intellectual and political skills were concerned, holding them to be treacherous, greedy, swayed by emotions and worst of all, lacking faith in themselves. Given his opinion of them, as well as his own singular character, Jinnah's claim to represent Muslims had little to do with any identity, history, culture or even interest that he might be said to share with his constituents. Instead his charisma seemed to derive from the very immensity of the difference between the leader and the led.

Insofar as Jinnah can be said to have represented Muslims at all, he did so in the way a lawyer does his clients, which is to say by focussing on their objective interests and from outside their own sense of themselves. Indeed he had little patience with the existential aspect of identity and always sought to turn what he considered its accidental facts into political principles. This lawyerly style of leadership seems to have been understood by Jinnah's Muslim followers, who remained undeterred by all attempts to tar him as a half-English heretic who ate pork and drank alcohol. So when the retired civil servant Sir Malcolm Darling embarked upon a horseback tour of northern India in 1946, speaking with country folk about their visions of the future, one of his Muslim interlocutors in the Punjab responded to a question 
about Jinnah's distance from Islamic norms by repeating the Qaid's own statement. Jinnah, he said, was a good Muslim leader because he could speak to Gandhi as a Khoja spoke to a Banya. In other words it was the Qaid-e-Azam's intimacy with his Hindu enemies that in the eyes of this pious Muslim made him an ideal leader (Darling 107).

As their lawyer, Jinnah thought that the problem with Muslims was their propensity to being seduced by petty theological issues and an outdated cultural or historical sensibility, thus forsaking what he imagined as their preordained role in the politics of India. This role had to do with Muslims performing their duty as India's chief minority in order to keep the majority true to their country's plural society. What interested Jinnah, in other words, was not the Muslim or even religious nature of this minority, but rather the way in which its constitutional position could be transformed into a political principle. And if Jinnah was used to accusing his fellow Muslims of degrading their community by stressing doctrinal matters over political ones, he appears to have felt real betrayal only when his Hindu friends in the Congress started doing the same under Gandhi's influence. Whatever else it was about, Jinnah's lifelong quarrel with the Mahatma had its alleged origin in the latter's attempt to reduce India's Muslims into a merely religious minority and thus deprive them of a political principle.

While Jinnah was certainly irritated by what he saw as Gandhi's dangerously unrealistic politics, this was not sufficient to provide the cause of his disenchantment with Congress. It was instead the Mahatma's first great movement of non-cooperation in 1919, which included the mobilization of Muslims for the cause of the caliphate, now supposedly at risk following the Ottoman Empire's defeat in the First World War, which seems to have particularly horrified Jinnah. Like the Hindu nationalists who tended to be his friends, Jinnah saw the Khilafat Movement as being a piece of political hypocrisy by which Gandhi obtained Muslim support for a reactionary cause, and in the process gave Muslim divines and their divisive theological concerns a political platform for the first time. Savarkar's book Hindutva was written precisely during this period to pose a Hindu politics against this new Muslim one. In later years ideologists of the Muslim League like the journalist Z.A. Suleri would see the Khilafat Movement, ostensibly the high point of Muslim mobilization in India, as nothing more than a "butchery" of their political life, even describing it as an absorption into "the fold of Hindudom" (Suleri 41, 53).

Unlike the Hindu nationalists, however, Jinnah's objections had to do with what he thought was the Mahatma's aim, reducing Muslims to a merely religious minority with no political principle or contribution of their own to the cause of India's freedom. He hadn't minded supporting the cause of a defeated Turkey against the colonial desires of victorious Britain and France, and like other Shia politicians of the time was thoroughly ecumenical in upholding the rights of a caliph who was considered nothing more than an illegitimate usurper within their sect. But to bring Islam into politics in order to bolster Congress, was, he considered, a foolish and ultimately dangerous move for all concerned, and one that forced him out of the party forever. The break was made in good theatrical style, after he stood up to Gandhi during the Congress's annual session in 1920 and, to the jeers and physical 
threats of the Mahatma's new Muslim allies, accused him of bringing religion into politics.(see Alvi 60).

\section{FALLEN ANGEL}

Having left Congress, Jinnah dallied for over a decade with other political parties formed among those conservatives and Hindu nationalists, like Motilal Nehru or Madan Mohan Malaviya, who were also exiles from it. But after the Round Table Conferences on the early 1930s that were meant to bring India's various interests into constitutional agreement, Jinnah decided to settle in England and practice before the Privy Council. The 1935 Government of India Act that resulted from these conferences, and pleased none of India's parties, widened the franchise further and called for elections to be held under separate electorates in 1937. Asked by a divided Muslim leadership to return and lead the Muslim League in these elections, Jinnah acceded and embarked upon a campaign to purge the party of "reactionaries," fill it with Congress Muslims and popularize it in alignment with the Congress, with which he'd reached an informal, power-sharing agreement. Congress emerged from the 1937 elections as the country's largest single party, though one that hadn't managed to secure the majority of the Muslim vote, which went instead to regional parties in Muslim majority provinces like the Punjab and Bengal. The Muslim League, in the meantime, though it hadn't won over the Muslim majority provinces, had done very well in areas where Muslims were in a minority, and so Jinnah fully expected to be taken into ministries in those provinces where they were a significant if not overwhelming force.

The Congress was entirely within its rights to refuse such an alliance, but went further and announced that it would be happy to include Muslim Leaguers who renounced their party to sign the Congress pledge, with Nehru even going so far as to make unwise comments about the League disappearing from Indian politics altogether. For Jinnah, this was not only a betrayal, but also what he described as a fascist and dictatorial tactic to eliminate opposition parties by a politics of bribery and blackmail, with the Muslims' true representatives, the Leaguers for whom they'd voted, being replaced by token Congress Muslims. He saw in this procedure nothing more than an attempt to destroy India's political plurality, or rather reduce it to a merely religious, ethnic or caste diversity. His own politics, by contrast, had always been about transcending the materiality of such identities and anchoring them to a political principle so general that it could be represented by anyone.

This was to be his last disappointment with Congress, for shortly afterwards Jinnah abandoned the language of minority rights altogether to announce that the Muslims were a nation, and thus to be dealt with on the basis of parity rather than by the counting of heads. Not coincidentally, this rejection of minority politics occurred once the internationalism of the League of Nations, with its famous minorities protections, entered into crisis with the rise of fascist wars in Europe and imperialist ones abroad. By 1940 Jinnah was asking for a vaguely defined state or states, independent or simply autonomous, in which this new nation could find a 
home. The name eventually adopted for this state had been thought up a decade earlier by a Cambridge undergraduate, and though it meant something like "land of the pure" was also an acronym describing "Punjab, Afghania, Kashmir, Sind and Baluchistan," with Bengal, the most populous Muslim province, being conspicuously absent. Jinnah's task was now to get the Muslim majority provinces to support the League and thus make it an equal player with Congress in Indian politics.

As founder of the "two nation" theory, Jinnah was often asked how Muslims constituted one. His standard response, running down a list of national characteristics, was always perfunctory, ending in the assertion that Muslims alone could fitly be described as a nation. But given the dispersed and diverse character of India's Muslim population, Jinnah's idea of nationality could have no bloodand-soil connotation, since history, geography and everything connected to them served to relate rather than distinguish Muslims from Hindus, and in doing so allow them to remain nothing more than a minority. Muslim nationality instead resided in nothing but the will alone, a self-sustaining and indeed devilish quality appropriately represented not only by Jinnah's own character, but also by his clear rejection even of the Islamic past and India's Muslim history in particular, which he on occasion compared to British imperialism. And this completely "unnatural" concept of nationality also made the Muslim "homeland" for which Jinnah fought a mere instrument of the national will, with Pakistan able to derive neither name nor notion from any past real or imagined. Indeed for Jinnah crucial about Pakistan was precisely that it was unprecedented.

We might say that only by rejecting what was given them by nature and history could India's Muslims exchange the role of minority for that of nation, if this latter was defined by religion conceived of not as the attribute of any particular population but rather as a universal idea or even an ideology. But if Muslim nationalism was to present itself as an ideology, or at least an idea transcending all that was given a people by history or nature, it could not be religious in any conventional sense. And it was this lack of religious familiarity in the Muslim League that explains its rejection by so many Muslim clerics, who preferred supporting the Indian National Congress, which was pledged to continue the colonial policy of granting them jurisdiction over an Islam defined by personal law and ritual practice. It also explains Jinnah's much discussed and yet inexplicably popular lack of religious feeling, which for him was simply an historical accident that made a national will possible among India’s Muslims.

In an interview with the Daily Herald on the $14^{\text {th }}$ of August 1942, Jinnah responded to a question about the possibility of a compromise between Hindus and Muslims with an epigram: Hindus want to worship the cow while Muslims want to eat it (Ahmad 409). Far from being a statement simply dismissive of Indian prejudices, Jinnah's laconic response actually takes them seriously. Unlike Gandhi, who took such prejudices seriously by trying to build a compromise between them, Jinnah wanted to dissolve them altogether by addressing the constitutional situation that he thought provided their basis. This was a situation in which various interests and constituencies, religious, regional and caste-based, had been created by imperialism in such a manner that turning India into a national state on some 
European model would annihilate the weakest among them. A national state of this kind would be Hindu by default rather than by intent, because its elimination of constitutional privileges like separate electorates would affect only minority groups as disadvantages.

The problem of India, thought Jinnah, was that it had adopted the language of democratic nationalism, with its majorities and minorities, in a situation where neither democracy nor nationality existed. But it was more than colonialism that prevented such a nation from coming into being, since constituting as they did a gargantuan population of 70 millions which also formed absolute majorities in a number of provinces, India's Muslims could by no means be considered a minority without deforming this term out of recognition. A constitutional solution to this problem was required, therefore, which for Jinnah meant nothing less than what he called a social contract. But this was only possible if all parties to the contract negotiated from a position of equality. Thus Jinnah's demands for parity in the discussions leading to independence, which Indian nationalists considered a disingenuous ploy to deny their numerical majority. On his part Jinnah saw in Congress attempts to refuse him parity a demonstration of Hindu dominance, since it was a specifically confessional majority that was being used to force a weaker community into the position of minority even before the establishment of a national state, one which he thought should be founded upon the heartfelt agreement of its constituting parts.

Jinnah accused the Congress of being idealistic by refusing to take Indian realities seriously. But he remained true to the Congress creed in other ways, a loyalty we can see demonstrated most clearly and ironically in the demand for Pakistan. One of Jinnah's catchphrases in the making of this demand was that the freedom of Pakistan presupposed that of India. Giving priority to Indian freedom here meant not that the Muslim League would hold up her independence until its demand for Pakistan was met, but rather that India could only be free as the kind of state Congress wanted it to be with Pakistan as its neighbour. Otherwise, whether as a centralized or federated state, it would only be some version of an empire, Mughal or British in form, where politics meant the state's manipulation of autonomous groups which were unable to constitute a citizenry. The freedom of Pakistan, therefore, meant the freedom of India, because in splitting the Subcontinent's enormous Muslim population between both countries, it would make possible the creation of "proper" majorities and minorities in each one, and thus a secular citizenship as well. So in the new India, for instance, Muslims would suddenly cease to exist as a nation and become what Jinnah called a sub-national minority, as too would Hindus in Pakistan.

The Qaid refused to consider a large-scale transfer of populations between India and Pakistan until the violence of partition forced him to agree to what we would today call the "ethnic cleansing" of a divided Punjab. Indeed he wanted the two countries to retain effective minorities for the sake of their own freedom, for only in this way, he said in an address to the Constituent Assembly of Pakistan in 1948, would Hindus cease to be Hindus politically and Muslims cease to be Muslims, both becoming the citizens of their respective states in a real sense, because of and 
not despite the other's presence (Burke 29). Only by eliminating what he thought were the impossible majorities and minorities of colonial India by its partitioning, could these religious groups lose their stranglehold on the region's politics and subside into civil society. And this would allow real democracies to emerge there by making possible the creation and destruction of temporary majorities and minorities based on a variety of different interests.

Apart from making a democratic citizenship possible, Jinnah thought that the minorities in India and Pakistan might also constitute a link between the two countries, one that could provide a basis for the relations and indeed mutual dependence of both. This scheme, branded by Congress supporters as the keeping of hostages, succeeded neither as an attempt to keep the Hindu and Sikh areas of Bengal and Punjab, provinces that the League claimed in their entirety, nor to retain such populations in other parts of what became Pakistan. This failure to shape the future of the state he had created can be blamed not only on the recalcitrance of others, but on the abstract idealism of Jinnah's own ideas, which is exactly what Gandhi did when speaking to Lord Casey, the Governor of Bengal, in 1946. For the Mahatma was one of the few who realized that Jinnah's ostensibly hard-headed political realism, one that disdained Congress calls for communal harmony as woolly idealism, was itself the most utopian of dreams dedicated to making visions like the social contract into political realities.

\section{SATAN INCARNATE}

The originality of Jinnah's political style, relying upon affectation and disdain, is made evident in books like Z.A. Suleri's My Leader, which appeared in 1945 with a drawing of Jinnah in high hauteur on its cover. The book's first chapter begins with a list of accusing quotations from Jinnah's enemies. "Jinnah Sahib is vain [...] Prouder than the proudest of Pharaohs [...] He is an egoist who would own no equal [...] Arrogant and uncompromising." To these Suleri responds in the following way. "Precisely this 'proudest of Pharaohs,' this 'egoist,' this 'India's political enemy Number One,' this 'arrogant and uncompromising,' this 'disruptor of India,' this 'essentially bad man' is MY LEADER." If Suleri can exult in his leader's demonization, it is because he recognized in the man's elegant disdain a force of negation that would break the language of Indian politics down to its most basic parts, so as to make what Jinnah called a new "social contract" out of the colony's state of nature. It is this force of negation that the great man's vanity exhibits, a demonic force that makes for an iconography full of grim and unflattering images, quite different form the handsome and urbane gentleman that we know Jinnah to have also been.

Quite different, too, from the iconography surrounding "Papa" Gandhi and "Uncle" Nehru, who was acute enough to recognize negation as Jinnah's greatest political weapon. Of course Jinnah imagined as an indomitable will in a frail body, an image calling for both obedience and protection approaches the cult of the Mahatma. But Jinnah's will is indomitable in the most self-consciously secular and civilian way, which is why it is satanic in Milton's sense, upheld by nothing but 
itself. And it is ambition, pride and other qualities of satanic solitude that make Jinnah heroic in a peculiarly modern sense, a heroism that the poet of Muslim nationalism, Mohammad Iqbal, glorified precisely in the figure of the Devil. For if certain mystics and poets in the past had seen in the Devil's refusal to bow before Adam at God's command a sign of his greater devotion to the latter, Iqbal made of Satan a modern hero, one whose disobedience signalled the virtue of independence or freedom, as well as the willingness to suffer for his convictions. And Jinnah, I want to argue, comes to fit this new, satanic image of heroism for India's Muslims, who were under few illusions about his heretical background, propensity to alcohol and pork and disinclination to pray.

Jinnah's rise to eminence was made possible by the increasingly parochial politics of the once dominant Muslim gentry in northern India, and by the political emergence on a country-wide scale of Muslim groups in other parts of the land. Jinnah himself was from one of these new groups, the merchants of Gujarat and Bombay, and his achievement was to bring them together with gentry, aristocrats and professional men from other regions, to lead the first popular party in India's Muslim history. How appropriate it was that this most unrepresentative Muslim should come to lead a party in which no group could claim to represent any other. It was the disparate character of the Muslim League that Jinnah's political style, his satanic solitude, addressed in the most original way. For might not his dandyism and love of masculine beauty have counter posed a self-fashioned and wilful sense of Muslim individuality to some impossible Muslimhood made up of common characteristics like belief, ritual or everyday practices? Jinnah, then, represented neither the Muslim past nor present, but perhaps, in the man's very departure from his community's various norms, nothing more than the future that was being imagined for it.

In one respect Jinnah's satanic character, depending as it did on what Nehru repeatedly described as his politics of negation, made him quite different from and indeed more devilish than the Devil himself. And this had to do with his refusal to tempt anyone - just as he was famously beyond all temptation. Jinnah certainly advocated the cause of Pakistan, but without ever painting it in the bright colours of utopia, as Congressmen were always doing for their vision of India. No doubt Muslim League propaganda came to develop its own rhetoric of a glorious if thoroughly ambiguous future, but Jinnah only ever spoke of Pakistan in terms of dry principles. So we often hear of those who were convinced by the mesmeric force of his personality suddenly losing faith in Jinnah's arguments once they were no longer in his presence.

In fact Jinnah himself admitted to being stirred by the seductions of Congress rhetoric, and so like Ulysses he not only chained himself to the mast of his political principles in order to resist the siren song of Indian nationalism, but had to make sure than his associates were protected from its temptations as well. During their talks of 1944, for example, Jinnah indignantly refused to allow Gandhi to address the League's working committee, since both the Mahatma and he seem to have realized the effect of Congress's temptations upon even the highest officials 
of the Muslim League. And indeed Jinnah had regularly to rein in his men when they appeared to be leaning too closely in Congress's direction.

Eventually it seems to have been a fear of the "Hindu Raj" Jinnah was constantly mentioning that came to dominate the popular imagination of India's Muslims, not any vision of a utopian future in Pakistan. But despite the increasing tempo of communal violence across the country, did this fear actually refer to any lived experience? Jinnah's accusations of Congress perfidy, at least until the Bihar riots of 1946, in which some ten thousand Muslims were killed, tended to rely upon infractions of principle rather than any real instances of persecution, which were after all to be found on both sides of the religious divide. Thus his contention that Congress forced all those under its provincial governments to sing its anthem as the national anthem, salute its flag as the national flag, abandon the Urdu language favoured by North Indian Muslims for Hindi and reverence India as a Hindu goddess in a song taken from a famously anti-Muslim novel of the nineteenth century. And when he did describe the miseries of "Hindu Raj" the only example Jinnah could proffer of its malignity had to do with discrimination and oppression among Hindu castes, so that he ended up asking Muslims to see their own future in the present misery of the "Untouchables." It was a curiously vicarious fear.

But if Jinnah disdained tempting either his friends or enemies with glorious visions of the future, it was his own immunity to temptation that truly made Jinnah into a satanic figure, one who famously refused Gandhi's offer that he should become the first prime minister of an independent India. Indeed he had similarly dismissed the Mahatma's desire that the League take the lead in forming an anti-Congress opposition in 1939, once Congress governments had resigned office in protest against India being taken into the Second World War without her consultation. Like Jinnah himself, Gandhi seems to have realized by the close of the 1930s that Congress was not India's sole representative, and that a quasi-democratic politics had already emerged in colonial India, with the existence of opposition parties that could not be reduced to creations of the British. So when a number of these parties, including the Hindu Mahasabha and the Muslim League came together to celebrate a "Day of Deliverance" once Congress resigned office, the Mahatma wrote to Jinnah recommending that he lead an opposition that might well assume government in an independent India.

Gandhi had understood that as India's biggest opposition party, the Muslim League had come to set the pattern and model for all the others. Dalits or "Untouchables", for instance, who were a minority everywhere in the country, adopted the League's pre-Pakistan politics of positive discrimination and constitutional safeguards, while the non-Brahmin movement of the South adopted a Pakistanistyle rhetoric of regional autonomy and even secession. Jinnah, of course, spurned all such attempts to lure him back to Indian nationalism, though he also appears to have held back from pressing his advantage and working towards the political fragmentation of India. Thus his attempts from the days of exile to build an alliance of minorities were abandoned once Jinnah opted for Pakistan, and he went out of his way to refuse support to low caste movements claiming autonomy, as much as to potentially secessionist agitations in different parts of the country. Was this because 
Jinnah wanted to be the only one to defy Congress, or because he envisioned his role as defending India from fragmentation as much as subjecting her to it?

\section{THE LAST INDIAN}

Jinnah was reluctant to utter the final word confirming India's partition, which has made historians speculate that he didn't really want a separation after all. This, I think, is an illegitimate argument, though Jinnah was certainly displeased with the way in which India and Pakistan eventually came to be created. He used to say that the last word was never spoken in politics, and this idea Jinnah apparently took so much to heart that the Viceroy, Lord Mountbatten, could only manage to extort a slight inclination of the head from him as a sign of agreement to India's partition and the creation of Pakistan. Hesitating at the last moment to take responsibility for the momentous future he had been instrumental in making for the Subcontinent, it seemed as if Jinnah wanted to assure himself of saving India by the same token as he would free Pakistan, since he thought of himself as being the well-wisher of both countries. We have already noted his reluctance to participate in the wider fragmentation of India as far as supporting caste and regional movements was concerned, and during the transfer of power Jinnah similarly appears to have made very little effort to bring the princes or Sikhs into his camp if only to discomfit India.

For his was a politics of principle, and what delighted Jinnah most about the emergence of two new states out of the Raj was that he thought such a double independence represented an achievement unprecedented in history, one in which these states had come into being not by war or revolution but as the result of negotiations among civilians that might be described as a social contract. The violence that soon broke out among refugees shifting in either direction disturbed Jinnah primarily because it tarnished this great achievement, with the movement of Hindus and Sikhs out of Pakistan serving to annul it altogether, since without minorities Pakistan no longer had any political meaning as India's counterpart. In fact he blamed the exodus on Congress, which Jinnah thought was deliberately spreading fears among Pakistan's minorities in order to pull them out of the country and thus destroy it.

Revealing his abstract and idealistic notion of politics, Jinnah spoke repeatedly during this period about forgetting the past and starting anew, as if history and experience could be undone so easily and by an act of will. But then he had never paid history much attention and was taken up instead by matters of principle above all. The violence that accompanied the independence of India and Pakistan served only to betray Jinnah's utopian desires for the future, signalling as it did the beginning of a war between the two countries that has been going on now, sometimes openly and sometimes surreptitiously, for over sixty years. And indeed the partition of India provoked the famously cold and unsentimental Jinnah to shed public tears for only the second time in his life, the first being at the grave of his estranged young wife. Like the Devil himself in Iqbal's rendering, Mohammad Ali Jinnah ended up as a tragic hero, undone by the very idealism of his politics. 
Even the most fervent nationalists among his Pakistani biographers have tended to see failure and tragedy in Jinnah's last year, not only because of the "moth eaten" country the Qaid famously said he had been given by a partition whose geography was entirely decided by the British, nor even because of the violence of Partition, but given his own marginalization in the new country he had done more than anybody else to bring into existence. Like Gandhi in this respect, who was also sidelined once India had become independent, Jinnah found himself with a great deal of constitutional power in Karachi, but isolated from his own government which had begun playing regional power-politics from a new base in Lahore. Dying of tuberculosis, Jinnah appears to have lost the affection of a number of his people in places like Bengal or Baluchistan. And eventually he probably even started fearing his own fellow-Pakistanis and co-religionists.

Jinnah had always pooh-poohed threats of assassination, and had once even been known to coolly wrest a knife from the hand of a would-be assassin who had slipped into his Bombay house. So despite warnings from the police and intelligence services that he might be targeted by Sikh or Hindu assassins, Jinnah insisted on riding in an open coach or unprotected car and refused to have walls built around his official residence in Karachi. During the ceremonial coach ride with Lord Mountbatten on the day when he was vested with the powers of Governor-General, Jinnah had annoyed the Viceroy, who was after all a military man, by claiming to have brought him through the event without an assassination attempt. But this courage was premised upon the supposition that the Qaid enjoyed the complete devotion of his people. On the very day that Gandhi was assassinated by a fellow Hindu, who accused him of betraying India to Muslim Pakistan, Jinnah asked for walls to be built around his residence (Bolitho 210). Had he realized that the threat of assassination came from one's own people rather than their professed enemies?

In any case it was the Mahatma who, in what the Qaid might be described as his last trick, ended up dying as a martyr for Pakistan and thus depriving Jinnah of that particular privilege. For Gandhi had been assassinated by a Hindu nationalist just before he set out on a pilgrimage to Pakistan, and was seen by his murderer as being so sympathetic to Muslims as to have practically offered them a state of their own. So it was no wonder that the Qaid's perfunctory statement of regret for the death of his old rival emphasized Gandhi's character as a great leader of the Hindus alone (Burke 99). Jinnah's own death had none of the public drama that Gandhi's did, though it occurred as a piece of theatre in the kind of intimate space that he so enjoyed dominating. Flown back to Karachi from the hill resort of Ziarat, Jinnah suffered anonymously in an ambulance that had broken down on a road choked by the ramshackle vehicles and pitiful belongings of Muslim refugees coming from India. It was in some sense a fitting end to one of the most remarkable political careers of modern times, that the leader who had always been an outsider should die as one among the wretchedness of the people he had almost singlehandedly put on the map of the world. 


\section{CONCLUSION}

Every biographer of the Qaid-e-Azam, like every historian of Pakistan, has wondered how a man as unrepresentative of Muslim norms in India as Jinnah was, should have become the most popular leader of his community. They have either dismissed his background and personality as inessential to the narrative of Pakistan's independence, or made Jinnah out to be more conventional than his contemporaries believed, whether as a Muslim or a "brown Englishman". But if we are to take biography seriously as a genre, neither of these options should be available to us, for the Qaid's character stands front and centre in all the accounts we have of him, each one of which strives to showcase his departure from the accepted standards of any culture. Even Gandhi, with all his originality and eccentricity, can be said to have represented a certain type as a political icon, if only that of a holy man or "half-naked fakir", as Churchill famously called him. And though it was always the Mahatma who was accused by his detractors of hypocritically playing a part, Jinnah has a much truer claim to making politics into a piece of theatre.

Yet the Qaid embodied no generic type, and in this way alone could he come to represent a Muslim community in which no group was able to speak for another. We might say it was the lack of hegemony in Muslim politics that made Jinnah possible as the kind of political icon he became, one whose own sectarian and regional background was both heretical and marginal enough to make him into a politician with no "natural" constituency. As someone absolutely singular and therefore satanic, he turned out to be the most appropriate leader for a dispersed community that possessed little political integrity. It was the need to reject bloodand-soil forms of nationalism that allowed the Muslim League to fix on a purely abstract national identity, one that made for a theatrical politics in which ideas and principles stalked the stage. Superficial because detached from narratives of national authenticity, and tenacious because based upon "logic" and ideas, Muslim nationalism found itself personified in the figure of Jinnah, who represented his people as a lawyer did his clients, by reducing the messiness of their actions to a set of ideals.

Reviews sent to author: 12 November 2017

Revised paper accepted for publication: 26 February 2018 


\section{REFERENCES}

Al Mujahid, Sharif (ed.). In Quest of Jinnah: Diary, Notes and Correspondence of Hector Bolitho. Oxford University Press, 2007.

Ahmad, Jamil-ud-din (ed.). Speeches and Writings of Mr. Jinnah, vol. 1 Shaikh Muhammad Ashraf, 1960.

Alvi, Hatim A. “The leader I knew best”, in Jamil-ud-din Ahmad (ed.), Quaid-e-Azam as Seen by his Contemporaries. Publishers United Ltd., 1976.

Baudelaire, Charles. The Painter of Modern Life and Other Essays, translated by Jonathan Mayne. Phaidon, 2005.

Bolitho, Hector. Jinnah, Creator of Pakistan. John Murray, 1954.

Burke, S.M. (ed.). Jinnah: Speeches and Statements, 1947-8. Oxford University Press, 2000.

Darling, Malcolm Lyall. At Freedom's Door. Oxford University Press, 2011.

Ispahani, M.A.H. Qaid-e-Azam Jinnah as I knew Him. Forward Publications Trust, 1967.

Jinnah, Fatima and Sharif al Mujahid (ed.), My Brother. Quaid-e-Azam Academy, 1987.

Khan, Sardar Shaukat Hayat. "The commander I served under”, in Jamil-ud-din Ahmad (ed.), Quaid-i-Azam as Seen by his Contemporaries. Publishers United Ltd., 1976.

Moraes, Frank. "The voice of India”, in Jamil-ud-din Ahmad (ed.), Quaid-e-Azam as Seen by his Contemporaries, Publishers United Ltd., 1976.

Savarkar, V.D. Hindutva: Who is a Hindu? Veer Savarkar Prakashan, 1966.

Suleri, Zia-ud-Din Ahmad. My Leader: Being an Estimate of Mr. Jinnah's Work for Indian Mussalmans. The Lion Press, 1945.

Wolpert, Stanley. Jinnah of Pakistan. Oxford University Press, 1984. 
